\title{
The Propaganda of the American Model and the Stench of Religious Imperialism
}

\author{
Birane Sene $^{1 *}$, Cheikh Anta ${ }^{2}$ \\ ${ }^{1}$ American and Caribbean Studies Laboratory \\ ${ }^{2}$ Diop University of Dakar, Senegal
}

DOI: $10.36348 /$ sijll.2021.v04i04.002

| Received: 26.02.2021 | Accepted: 31.03.2021 | Published: 13.04.2021

*Corresponding author: Birane Sene

\section{Abstract}

American messianism is based on the idea that the United States is the bearer of a divine message to all nations. This concept lies on several realities on which a certain mythology of America has been built over the centuries. In short, it is the idea that the United States is the best hope for solving many of the world's major problems and should show the way to other nations. This theory considers the United States to hold a special place among the nations of the world in terms of citizenship, historical development, political and religious institutions. Self-esteem is therefore a valuable commodity for any country, but the problem is that when a nation like the United States begins to think it has a mandate from heaven and is convinced that it cannot fail or be led astray, such a leadership would be regarded as imperialistic. The American model is now taken as a huge soft power propaganda using religious arguments and tools to ensure its domination over the world.

Keywords: Imperialism; policy; Propaganda; Messianism; Model; Moral; Religion; Values.

Copyright ( $\odot 2021$ The Author(s): This is an open-access article distributed under the terms of the Creative Commons Attribution 4.0 International License (CC BY-NC 4.0) which permits unrestricted use, distribution, and reproduction in any medium for non-commercial use provided the original author and source are credited.

\section{INTRODUCTION}

The first settlers of the United States dreamed of a country where all citizens would engage in the struggle for the creation of a New World. The main ambition of this New World was to become the beacon of the world, in other words, the light that would shine on the world and enlighten it with its values. This purpose was reflected in 1630 in the words of John Winthrop aboard the Arabella, for whom this New World will be like a "City upon a Hill". The birth of this nation then marked the beginning of a new history of a country destined to be the great nation in the future. The destiny of this new found land is to lead other nations and to be the embodiment of the progress of humanity which no earthly power could oppose because it was guided by providence.

This religious belief is one of the constants of the United States foreign policy. It is also found in the expression "Manifest Destiny" which is America's duty to cover the entire continent granted by providence to allow the free progress of millions of inhabitants and their descendants even if it is to the detriment of native Indians. It is this "Manifest Destiny" that has been used again to justify a policy of conquest and territorial expansion. The concept evolved to explain the propensity of Americans to give a providential explanation to their history, as well as their future as a powerful nation. This same concept will later serve as an ideological basis and justification for their interventionist attitudes in the world's affairs. This allows them to have the right of scrutiny over others nations that do not share these so- called universal values. Carrying out this task requires formatting the rest of the world to the American model that is to say, spreading the supreme values upheld by the United States which is regarded as an imperialistic project.

This article intends to shed light on the United States' desire to internationalize its model and values which is interpreted as a new form of imperialism. The first part of this work will lay the emphasis on the supposed divinely inspired American model or way of life promoted all over the world through the portrait of its beliefs to hold universal values. The second part will analyze the new American imperialism supported by religious soft power institutions to carry out its foreign policy.

The messianic attitude of the United States around the world

In the course of history, it must be said that most of the great powers considered themselves 
superior to their rivals and believed that they were promoting the greater good when they imposed their preferences on others. The English people thought, they carried "the white man's burden", while the French colonialists talked about the civilizing mission to justify their empire. Likewise, many officials of the former Soviet Union believed that they were leading the world towards a socialist utopia, despite the cruelties inflicted by this communist authority. So when American people proclaim that they are exceptional and indispensable, they are simply the last nation to sing a familiar old song. Thinking of being special because of the beliefs and moral values defended worldwide is the norm among the great powers like America. Today, we see that the rebuke is general, as anti-Americanism has become obvious especially in countries that challenge American leadership which merges with the representative of God on earth.

\section{The fated conception of American leadership in the world}

American messianism has its origin in the birth and in the spirit which animated the pilgrims Fathers when settling to their new found land. It should be noted here that this ideology dates back to the very beginning of the construction of the United States of America by a large part of Anglo-Saxons, fleeing the old world and its depravities. These migrants, carrying with them their resentments and their ideals, arrived on this new land that was then America. They thus hoped to build a world in keeping with their expectations, a world forged on other values and created to show the way to other nations. Many figures in American history have taken for granted this ideology that America is a "City upon a Hill" and that the eyes of all people should be upon this country with its "chosen" citizens. One of the most famous Pilgrim Fathers John Winthrop has planted the seed of this American exceptionalism when he said:

"We must always think that we will be a City upon a Hill. The eyes of all people are upon us; so that if we should fail, before our God, in the mission which we have undertaken, and if he thus withdraws his support from us, we will become the reproach of the whole world, we will allow our enemies to denounce the ways of God [...] [1].

This idea developed by John Winthrop will be repeated by most of the American leaders so much so that leading the world has become the destiny of the country as it is deeply rooted in the minds. This Idea will be a leitmotiv for many Americans who believe that American leadership is divinely inspired .Thomas Woodrow Wilson, president from 1913 to 1921 , had previously affirmed by professing his faith in the belief that God has chosen America to rule the world. He affirms: "God presided over the birth of this nation... We are chosen to show the way to the nations of the world as they walk in the paths of freedom. America defends human dignity (...) America is the hope of humanity [2]".

Many other American presidents and scholars have made such declarations presenting their country as a gift from heaven. The former President Ronald Reagan told in a meeting that "there is a certain divine plan which had placed America here" and quoted Pope Pius XII as saying, "In the hands of America, God has placed the destinies of a grieving humanity [2]." President Bill Clinton believed that the United States was indispensable to the construction of stable political relations, and Samuel P. Huntington was convinced that American primacy was central to the future of freedom, democracy, open economies and international order in the world. The Journalist Michael Hirsh went even further, writing in his article "At War With Ourselves" that "America's global role is probably the greatest gift the world has ever received in many centuries of all the archived history [3]." As for Tony Smith and John Ikenberry, they underlined the contribution of America and its role in the diffusion of democracy and the promotion of a world order which is liberalism.

Given all of these beautiful declarations that American leaders have given themselves, it is therefore clear that most Americans see their country as an overwhelmingly positive force in world affairs. It goes without saying that countries value their own special qualities but these same countries are often not courageous enough to recognize that they also have flaws. The United States perhaps has the same defects against which it has made it a mission to eradicate in others. The only thing about these self-glorifying portraits that do not match with reality is that it is mostly a myth or a pretext to justify the will of the powerful states to dominate over the weak.

The United States then thinks that it behaves better than other nations and that the superiority of American ethical values carried by providence authorizes them to act as a judge and apply justice in the world. Statements of American exceptionalism are premised on the belief that the United States is a nation of unique virtue, one that loves peace, nurtures freedom, respects human rights, and embraces the rule of law. Judging by these previous declarations of Americans famous leaders, they think that their country is behaving much better than others and certainly better than other great powers.

The concepts of democracy, religious freedom good governance, and human rights protection are regarded as the United States dearest values that should be internationalized. President George W. Bush offered a similar view in 2004, stating that he had the certainty and belief that "America has a mission, a call from the Creator of Heaven to spread freedom around the world, through a current of religious expression [4]."This so far hidden aspect of the religious dimension of 
American involvement has abruptly appeared in President Bush speech. This slip of the tongue will have tremendous impacts in the war against terrorism that he has named himself as a crusade.

That messianic rhetoric is still heard in the very subconscious of Americans who are pretending to fulfill God's plans in their actions. The extracts from a speech by US former Secretary of State Hillary Clinton published in September 8, 2010 by the newspaper Le Figaro are further tangible proof of this. This statement, which Mrs. Clinton made to the Council on Foreign Relations think tank, has very telling sequences showing that divine mission of the United States to protect the world.

Solving foreign policy issues today requires us to think regionally and globally in order to see the interactions and connections between countries, regions, interests, and to bring people together as only America can. The world is counting on us. When old adversaries need an honest middleman, when fundamental freedoms need a champion, people turn to us. When the earth trembles or rivers overflow, when pandemics rage or latent tensions turn to violence, the world looks towards us... I see it in the faces of the people I meet in my travels, not only young people who dream of America's promises of opportunity and equality, but also diplomats and politicians.... They can see the loyalty to principle and confidence in action that comes with American engagement. And they expect America not only to engage, but to lead. America is the best hope in a dangerous world [5].

As it can be noticed, this kind of statement is a refrain of an old song by American leaders. An almost religious conception that refers to the idea of the redeemer and the bearer of salvation for mankind. This speech and the preceding other declarations are like a prophetic mission entrusted to the United States and its leaders to save mankind from all evil as only God knows how to do so. A crucial component of this ideology is the belief that the United States has a divinely prescribed mission to lead the rest of the world. Most statements of American exceptionalism assume that America's values, its political system, and its history, are unique and worthy of universal admiration. They also imply that the United States is both destined to play a distinct and positive role on the international stage. Americans are thus giving themselves credit for positive international events and hold in high esteem their moral judgments when it comes to make decisions.

\section{American Leaders and the worthiness of their moral principles}

The puritans' history shows how much they believed in the idea of their election and predestination to live in the Promised Land of America. The native populations were naturally unelected persons who had to be excluded from the American Eden by violence and death. Violence in America therefore began from these periods of confrontation with the Amerindians until the Revolutionary War which restored to the Puritans and their descendants their American Eden. It is true that the United States has made undeniable contributions to peace and stability around the world over the past century, including the Marshall Plan, the creation and management of the Bretton Woods system, its rhetorical support for the fundamental principles of democracy and human rights and its military presence, especially stabilizing in many countries of the world. The problem is that the belief that all the flow of good things comes from its wisdom overstates America's contribution to the world. Indeed, international politics is a relation of contact and states, even powerful ones, must sometimes jeopardize their political principles for security and prosperity. Nationalism is also a powerful force that inevitably highlights the virtues of the country while ignoring their own defects.

Thinking that American moral principles should be widespread over the world is a mistake as morality can be a double edge knife. The United States can feel at ease in situations that are judged morally acceptable from the inside while the other countries hold the same situation as totally at odds with their moral principles. As an example, in 2011, the United States hinted that they could withdraw aid from countries which did not respect gay rights. In $27^{\text {th }}$ June 2013, President Barack Obama meeting the Senegalese president Macky Sall advocated gay rights equality in a country where homosexuality is outlawed. The Times newspaper reported the following extract in its headlines the following day saying:

Obama urges gay Rights to Africa during his trip to Dakar. The US President Barack Obama has called on African governments to give gay people equal rights by decriminalizing homosexual acts. President Obama made the comments in Senegal after meeting president Macky Sall. President Macky Sall said Senegal was a very tolerant country but it was not ready to decriminalize homosexuality [6].

As a reminder, homosexual acts are still a crime in 38 African countries, where most people hold conservative religious views. The gay issue is still however a born of contention in the American society and yet President Obama is advocating it outside America. We know that since 2013, many Americans have been living unwillingly in one of thirteen states, in addition to the Federal District, recognizing gay marriage even if other states are still against. The reason for that surprising situation is related to The Defense of Marriage Act voted in1996 and which has become unconstitutional in June 2013. Many Senegalese people were frustrated about the attitude of President Obama, demanding from African countries what we cannot get from his own citizens. 
Another example denying the superiority of American morality is its fight to stop the bloom of mass destruction weapons. The strained relations between the United States and most of Middle East countries accused of threatening peace and security in the world are based on peace and security principles. Some people cannot understand this American hypocrisy which consists of criticizing the others or fighting them for principles that are not respected in its own country. Bernard Williams made the following remarks about the moral principles advocated in American policy and the reality:

"The United States should bear in mind that the content of moral values is not absolute or universal but always varies according to the social practices and traditions of human groups. The validity of a moral judgment depends only on the consensus it elicits within a given group. In 2003 for instance, the Unites States attacked Iraq for developing weapons of mass destruction. Iran was also accused of developing a nuclear program for military purposes and has been under sanctions for years. At the same time, America is still reinforcing it armament forgetting that the best way to protect the world against weapons is not to make them anymore [7]."

Therefore it is more accurate to say that in ethical debates, there is no truth but better arguments and it is incorrect to treat moral arguments as moral truths. It must also be said that the military actions carried out by the United States to make the world safer have directly or indirectly caused the deaths of thousands of people, especially in recent decades. All this, to suggest that America is far from being perfect and that its moral principles may offend the sensibilities of other nations it is more likely to criticize for violence and the absence of democracy. Even if we admit this image of America displaying virtue and philanthropy in a world facing all sort of challenges, the fact remains that America's way may not suit the others. Another important thing to be taken into account is that if the American democratic model is a gift from God, who should ensure its distribution throughout the world? While the United States possesses certain qualities, an unbiased look at the historical record belies most claims of America's moral superiority.

Far from being a single state whose behavior differs radically from that of other great powers, the United States behaved like any other state, pursuing, first and foremost self-interest, seeking to improve its position by devoting itself to purely idealistic pursuits rather than true disinterested fights. Like the great powers of the past, they are convinced that they are different and better than everyone else. America certainly has its own special qualities, like all countries, but it is nonetheless a state included in a competitive global system that it itself has greatly contributed to its dissemination. It is much stronger and richer than most, and its geopolitical position is remarkably favorable. These advantages give the United States a wider range of choices in how it conducts foreign affairs, but they do not ensure that its choices will be morally good as its leaders want them to be believed, let alone exportable to other societies.

\section{Religious propaganda as the bedrock of American imperialism}

In American Eden, communism was seen as an evil enterprise which can be likened to a set of injunctions from Satan to oppress innocent and helpless individuals. American messianism merges today with a renewal to embody the role of the missionary of democracy and freedom all over the world. Religious freedom and the persecution of minorities in the eyes of many American leaders is the most important cause to be defended in the United States and around the world. With the International Religious Freedom Act, the US State Department maintains a Global Religious Freedom Office. The countries appearing which do not respect religious freedom are classified in the black list of countries of particular concern and are therefore liable to sanctions. By the same token American churches and religious organizations are spreading Christianity by their actions and sponsoring to reach many countries. For many people, this attitude is a proof that the ambition attributed to the United States of wanting to internationalize its model through religious values is a reality.

\section{The advocacy of religious freedom and the widespread of American beliefs}

Today, religious freedom is recognized by international conventions as one of the fundamental inalienable human rights, and the United States works to protect these rights, not only nationally but around the world. John Hanford who was the State Department's Ambassador for Worldwide Religious Freedom made the following statement: "Freedom of religion is for us a fundamental right enshrined in the First Amendment to the Constitution of the United States and is deeply rooted in our history and in our national temperament [8]." The problem today is America's current relationship and its responsibility to face the rise of global cultures. The issue raised here is to what extent can a religious and cultural model be transferred to other societies within a global context? This is surely a question that arises but the answer to which is not obvious, especially in a world where everyone is looking for its own identity.

When facing institutional crisis and the collapse of the social bonds in several countries, poor populations often turn to religion to be able to endure misery. Meanwhile, churches and sects thrive in saving human lives by giving hope to these populations. A particular note is the case of religious movements of American origin, which are for the most part Baptist, Pentecostal and Evangelical. At the same time, this 
phenomenon worries several observers such as Andre Corten, who sees it as "an instrument of US imperialism, charged with proselytizing its values and their vision of the world [9]."

The fact of placing international relations in a set of religious values is not new in the United States, but what is worrying during this 21 st century and which raises questions at the very limit of concerns is the rapid progress and almost uncontrollable of these religious movements which have established themselves all over the world. Thus religious movements now are thousands in Latin America, Asia and Africa, winning the support of a large number of people. According to the Pew Forum on Religion and Public Life, there are now 64,000 Protestant missionaries on the roads, most of them evangelicals. This agency gave the following figures for details:

The SBC alone supports 4,946 missionaries in 153 countries and baptized 451,000 new believers outside North America in 2000. According to a poll conducted by Todd Johnson on February 28, 2012 on Christian missionaries around the world. The United States remains the number one missionary donor country in the world, followed by Brazil. The American Board of Commissioners for Foreign Missions (ABCFM) is also the largest missionary organization in the world. Of the approximately 400,000 Christian missionaries in the world, 127,000 are believed to be from the United States [10].

This religious contingent continues to grow by associating evangelization and charitable works. The action of evangelical pastor Rick Warren against hunger, poverty, disease, corruption or even the loss of spiritual landmarks reveals the exceptional capacity for mobilization and the dynamism of these American religious groups. The National Association of Evangelicals created in 1942 makes it possible to operate charities with unique efficiency, thanks to networks of devotees who are generous with their time and money. After 18 months of existence, Warren's network charity program had already sent 4,500 members of his Church to 47 countries. In 2015, his church sent members to serve in 197 countries that is 57 more countries that the Peace Corps has served.

It must be said that it is Evangelical and Pentecostal Protestantism that are the fastest growing religions today. It is estimated that on average an Evangelical Church opens every ten days. Among them are many spontaneous independent Churches, those whose changing and recomposed character precisely complicates integration into the city. A community split into myriads of names but which has in common a great dynamism and an unequaled rate of practice outside the United States, in particular in China, Latin America and in Africa. The reason for this rapid dissemination of American religious organizations in the world is mainly legal dispositions favoring religious practice that the United States intends to internationalize.

The Amendment to the Bill of Rights states that "Congress shall not make any law which affects the establishment or prohibits the free exercise of a religion [8]." Article 18 of the Universal Declaration of Human Rights affirms also that everyone has the right to freedom of thought, conscience and religion. This right implies the freedom to change one's religion or belief as well as the freedom to manifest one's religion or belief alone or in common, both in public and in private, through teaching, practice, and worship and performance rites. The American Evangelical Protestants insist that their country should act and pronounce in this direction on the international scene which can be considered as already acquired with the Religious Freedom Act intending to protect free religious practice not only in the United States but abroad .

\section{Religious institutions as soft power tools for imperialism}

For the past twenty years, many religious organizations have mobilized to promote religious freedom, but above all to denounce and fight against religious persecutions. These actions in particular concerned situations in which Christians were denied free religious practice around the world. Countries like Sudan, Nigeria, Saudi Arabia, China, but also the Palestinian authority have come under heavy criticism for the treatment of Christians. In February 2003, with the violence between Muslims and Christians in Nigeria, the magazine "Christianity Today" suggested lobbying both with the American government and the Nigerian embassy in the United States. They wanted to fight against the imposition of Sharia, Islamic law, on Christian Nigerians in the south.

This kind of approach is a proof for some people that the United States wants to promote its beliefs using religious institutions and the Free Religious Act in protecting American citizens to invade other countries by setting worship places. This is sometimes not without causing problems for the local authorities of the countries concerned. For example, the evangelical group "New Tribes Mission", based in the United States and active in indigenous communities in southern Venezuela, was expelled by the President of Venezuela, Hugo Chavez, in October 2005. On August 19, 2013, President Paul Biya from Cameroon ordered the closure of around 100 Pentecostal churches in Yaoundé. These episodes are just the tip of the iceberg in the presence of American churches on the international stage.

The same situation is prevailing in Senegal where the Archbishop of Dakar Theodore Adrien Sarr declared in 2011 that he was "aware of this problem and attentive to the situation created by these new sects 
[11]." The Muslim dignitaries also deplored the invasion of the country by some Christian sects. Imam Assane Seck, Deputy Secretary General of LIPS (League of Imams and Preachers of Senegal) said: "These sects pose a threat to Islamic-Christian dialogue. There needs to be solidarity between Catholics and Muslims to face these people and preserve the achievements that make Senegal a country of religious tolerance. Protestant churches have been here for more than 150 years but we have never seen them behaving like these sects [11].

The LIPS organization, which has more than a thousand Muslim religious leaders and guides in Senegal, has launched a campaign against the proselytism of evangelical-type churches. On June 26, 2012, the "Kingdom of God Church" facilities were destroyed by demonstrators. These demonstrators accuse the leaders of these evangelical churches of diverting young people from Islam to their sect. Although it is clear that church census initiatives in several African countries are initiated and funded from the United States, however, as in South America, there are no very structured theories relating to the direct support of evangelical or Pentecostal churches aimed at countering harmful influences, communist or otherwise.

We remember that, in the 1980s, Ronald Reagan was very afraid of Marxist infiltration and liberation theology within the Catholic Church in Latin America, and so, naturally the development of anticommunist competitors was a good idea for him. But the mere fact that these affiliated churches can receive funding or support from sisterly American institutions is already for many people a sign of imperialism even if some churches are at the same time carrying development projects. American origin, promotion of Anglo-Saxon values, integration of politics, investment in the social field, external support, offensive evangelism, proselytism among Muslim populations and sometimes open interfaith conflicts, as in Nigeria, that is the picture describing the attitude of these religious organizations. In such a situation, nothing more is needed to let the specter of infiltration arises for geopolitical purposes. It goes beyond a simple "Americanization" of Latin American, Asian and African Christianity. Madeleine Albrigt in her book "The Mighty and the Almighty" spoke of Africa as a place of competition between religions. She quotes a Ugandan young man complaining about that American proselytism in Africa:

You see, we are heading for a clash. The United States will never stop fighting you until you turn away from your religion. Nowhere else in the world has religious revival been more evident than in Africa ... Meanwhile the number of Africans claiming to be Evangelical Christians has increased in just three decades from 17 million to around 125 million and over in total, there are now over 350 million African Christians. The Bible and related books have been translated into hundreds of local languages and dialects [12].

For many people, these Churches are accompanied from the outside, spreading American values thus colonizing the world spiritual space. The support of sister institutions is more than obvious because these churches provide financial means to some local churches. Likewise, they supply the pastors with material: brochures, videos, etc. The bestsellers of American televangelists are available in many bookstores, just as "made in the USA" TV programs are looped on certain television channels. Some American preachers, like stars, make real tours in the world, filling the stadiums and selling their products. However, in general, the risk of friction with the governments in place does not hold back the community, which defends its right to freely practice its religion.

Many evangelical groups, such as "Samaritan's Purse", "Religious Freedom Coalition" or "China Aid Association", also conduct charitable actions abroad, in Washington or locally, within their churches. The Assemblies of God today, like other evangelical and Pentecostal institutions, have several hundred missionaries who travel around the world constantly to bring the good word. These Anglo-Saxon churches have set up many humanitarian NGOs, such as "Samaritan's Purse", which work on the African ground with local Pentecostals. World Vision founded in 1950 by Robert Pierce, an American evangelical pastor missionary, is present today in 98 countries around the world and promotes Christian values.

World vision's mission statement is: «to follow our Lord Jesus Christ in ministry among the poor and oppressed, promote justice and bear witness to the good news of the kingdom of God" $\left[{ }^{1}\right]$. The organization has a "Christian Commitment Department" which deals with partnerships with churches, missions and other religious denominations in the countries where it is present. Obviously, it's not just America in this frantic race to dominate the world and impose its cultural and religious values. Many other countries are also its fiercest competitor in this area. So nations that consider themselves blessed, must act beyond their own interests and defend values and rights that they believe to be universal. It is their obligation to use all their means to ensure that their governments can dominate sociologically and spiritually but with the risk of creating global instability.

\section{CONCLUSION}

America's messianism has started with the foundation of the country by religious dissidents coming from England. This self-centered ideology grows up with time and reaches its highest level after the September 11, 2001 attacks. The destruction of the 
Birane Sene \& Cheikh Anta., Sch Int J Linguist Lit, Apr, 2021; 4(4): 93-99

World Trade Center, one of the symbols of American power, will launch this country into war against countries, organizations and individuals that its authorities qualify as partisans of evil and countries of the "axis of evil". If there are nations driven by the forces of evil, there must also be others only concerned with good. America will, therefore, rely on the notion of City upon a Hill and engage it hard and soft power to spread it model around the world.

This propaganda of the American model rests upon the conviction that this nation has a specific role to play in the world and has to show the way to the others countries. In the fulfillment of that so called mission, the religious aspect is so flagrant that American intervention in world affaire is regarded now as imperialistic. Many countries consider the United States power oppressive and arrogant as its religious soft power does not help the other to find their own ways. This leadership regarded as positive for many Americans has created a feeling of domination over other people with more and more protests entangled with religious convictions.

\section{REFERENCES}

1. John, W. (2009). A Modell of Christian Charity, New Edition, New York: Evergreen Review.

2. John, B. JUDIS. (2005). The Chosen Nation: The Influence of Religion on U.S. Foreign Policy, New York: Policy Brief.
3. Michael, H. (2012). En guerre Avec Nous-mêmes, Paris : Cultures et civilisation.

4. Tom, C. (2004). "Bush puts God on his side" London: Americas.

5. Alexis, B. (2010). «Les USA le meilleur espoir selon Clinton » Le figaro Flash actu $\mathrm{N}^{\circ}$ du 08 Septembre 2010.

6. Thomas, F. (2013). "Obama urges gay rights in Africa during trip to Senegal" The Times $\mathrm{N}^{\circ} 27^{\text {th }}$ June 2013.

7. Bernard, W. (2010). Moral Luck, Cambridge, Cambridge University Press.

8. Carl, A. (2005). Religion et politique dans l'esprit américain » Giovedi, Année I N.2 Septembre, 12.

9. André, C. (2001). Explosion des pentecôtismes africains et latino-américains: Instruments de l'impérialisme ou culture populaire ? Le Monde Diplomatique, $\mathrm{N}^{\circ} 15$ décembre 2011.

10. Scott, K. (2005). "Pew Forum on Religion and Public Life and Center for the People and the Press", N 3 Août 2005/ in pewforum.org.

11. Charles, S. (2011). Attaques répétés au Sénégal contre les 2 églises évangéliques $\gg \mathrm{N}^{\circ}$ du 3 Juillet 2011.

12. Madeleine, A. (2003). The Mighty and the Almighty reflections on power, God, and world affairs, New York: pan Books. 